\title{
Towards a more robust approach for the restoration of mangroves in Vietnam
}

\author{
N.T. Hai ${ }^{1,2} \cdot$ B. Dell ${ }^{1}$ - V.T. Phuong ${ }^{2} \cdot$ R.J. Harper ${ }^{1}$ \\ Received: 12 May 2019 / Accepted: 10 January 2020 / Published online: 11 February 2020 \\ (C) The Author(s) 2020
}

\begin{abstract}
- Key message Globally, mangrove forests are under threat from a range of causes. They also represent a large potential form of climate mitigation and adaptation via reforestation, and this investment may contribute to restoration efforts and reverse mangrove decline. There has been significant (c. 200,000 ha) mangrove reforestation and restoration activity in Vietnam, and these projects provide indicators of the causes of project failure or success, and what is required for more complex restoration of ecosystem services. Failure in mangrove programs can be attributed to lack of understanding of the reasons for the loss of mangroves, poor site and species selection, and lack of incentives to engage local residents in the long-term management of restored areas. Overcoming these impediments and adopting monitoring and reporting procedures that consider both areal success and ecosystem function will provide a more robust approach for future mangrove restoration projects.

- Context Over the last three decades there has been considerable (c. 200,000 ha) state and non-government investment in mangrove programs in Vietnam. The main objectives have been coastal protection and stabilization and the production of forest products, with fisheries, climate mitigation, and adaptation and ecosystem restoration as minor objectives. These have had reportedly varied success in terms of long-term survival rates. Much focus has been on the use of mono-species rather than restoring functioning mangrove ecosystems. - Aims This paper provides an overview of the status of mangroves in Vietnam and considers the effectiveness of mangrove restoration efforts based on an analysis of these reports. We develop and recommend approaches to make future mangrove restoration programs more effective.

- Result First, we provide an overview of mangrove distribution and mangrove deforestation in Vietnam. Second, we analyse major mangrove projects by investigating their objectives and exploring reasons for their success or failure. Third, we suggest approaches for successful mangrove restoration activities in the context of current international agreements on climate change. Failure in some mangrove restoration programs in Vietnam can be attributed to lack of understanding of the reasons for the loss of mangroves and of site hydrology, poor site and species selection, lack of long-term monitoring and management, and lack of incentives to engage local communities in the long-term management of restored areas. Removal of these impediments will increase restoration success.

- Conclusion The widespread and varied mangrove reforestation and restoration activities in Vietnam allow the analysis of different approaches and identification of the key factors leading to restoration success. These include care with species selection, having clear protocols for monitoring and reporting and implementing a co-management approach that provides incentives for local communities to benefit from the management of restored mangroves.
\end{abstract}

Keywords Mangrove forests · Vietnam - Deforestation - Reforestation - Restoration · Rehabilitation · Management . Community-based restoration

Handling Editor: Andreas Bolte

This article is part of the topical collection on Forest Adaptation and Restoration under Global Change

R.J. Harper

r.harper@murdoch.edu.au

1 Agricultural Sciences, Murdoch University, Murdoch, WA 6150, Australia

2 Vietnamese Academy of Forest Sciences, Hanoi, Vietnam

\section{Introduction}

Ecosystems services are defined as the well-being provided to humans by natural ecosystems (Millennium Ecosystem Assessment 2005). Mangrove forests provide important direct and indirect coastal ecosystem services such as food and raw materials for local people, fish nursery maintenance, coastline protection, erosion control, water purification, and ecotourism (Barbier et al. 2011). Mangroves are also one of the most 
carbon-rich ecosystems in tropical regions with mean carbon densities of $1023 \mathrm{t} \mathrm{C} \mathrm{ha}^{-1}$ (Donato et al. 2011). Therefore, although covering less than $1 \%$ of the total tropical forest area, mangroves account for about $3 \%$ of carbon stored by the world's tropical forests (Alongi 2012). Furthermore, with only $0.5 \%$ of the total coastal ocean area, mangroves account for $14 \%$ of carbon sequestration in the world's oceans (Alongi 2012). As a large sink of carbon, mangroves play an important role in the global environment, especially in climate change mitigation. When mangrove ecosystems are degraded or deforested, they not only lose capacity as carbon sinks but also contribute to greenhouse gas emissions (Wylie et al. 2016). Globally, mangrove deforestation may release 0.07 to $0.42 \mathrm{Gt} \mathrm{CO}_{2} \mathrm{yr}^{-1}$ (Donato et al. 2011).

Mangroves are one of the most threatened ecosystems in the world. In the two decades from 1980 to 2000, over $35 \%$ of the total mangrove area was lost globally (Valiela et al. 2001), and up to 2012, the total mangrove area declined from 19.8 to 14.7 million ha worldwide (Valiela et al. 2001; Kauffman and Donato 2012). It is estimated that the mangrove decline rate is even higher than that of inland tropical forests and coral reefs (Duke et al. 2007). Southeast Asia has suffered the greatest loss with about half of the region's total mangrove area, corresponding to $15.4 \%$ of the global mangrove area lost in the period 1996-2010 (Thomas et al. 2017).

In Vietnam, the area of mangroves was reported to be 408,500 ha in 1943. However, under the impact of chemical attack during the Second Indochina War, 124,000 ha of mangrove forests were destroyed from 1965 to 1970 (Westing 1983; Hong and San 1993). Mangrove deforestation in Vietnam has continued with about $0.25 \%$ of the mangrove area lost per year from 2000 to 2012 (Richards and Friess 2016). Apart from mangrove deforestation, mangrove degradation also has been an issue in Vietnam. Only $21 \%$ of the existing mangrove forests in Vietnam were natural forests while the remainder were re-planted (McNally et al. 2011).

Because of important roles in supplying economic and environmental values, mangrove restoration projects have been implemented by many countries. In particular, mangrove restoration programs received renewed impetus after the tsunami in Indonesia in 2004 and the Haiyan typhoon in the Philippines in 2013 (Wolanski and Elliott 2015; Barnuevo et al. 2017). Mangrove restoration in Vietnam also has received attention because of that country's long coastline that is exposed to erosion. From 1975 to $1998,67,600$ ha of mangroves were planted in southern areas, mostly with state funding (Spalding 2010). In addition, mangrove restoration programs have received international support, with recent particular interest in their role in carbon mitigation. However, there are no assessments on the effectiveness of the previous programs.
In the literature, the terms "rehabilitation" and "restoration" are often used interchangeably (Dale et al. 2014). However, they have different ecological contexts. Field (1999) defined rehabilitation as the process of converting a degraded ecosystem to a more stable condition while according to Lewis (1989) restoration refers to returning an ecosystem to a preexisting condition. As noted by Bosire et al. (2008), a wide range of project types with quite different aims were previously considered as "restoration". This includes "reforestation" which is a term used to refer to "planting trees in areas which were formerly forested and where the site conditions have not been degraded since removal of mangrove cover" (Schmitt and Duke 2014). Reforestation can comprise single or multiple species that grow to meet the definition of a forest on the basis of area covered, height and canopy cover (FAO 2012) but has a narrower role than restoration. Therefore, we use the terms "restoration" and "reforestation", where appropriate.

In this paper, we provide a description of the pattern of change in mangrove resources in Vietnam, explore the reasons for the success or failure of conservation, reforestation and restoration projects and develop recommendations for a more robust approach for mangrove restoration.

\section{Methodology}

This paper used grey data collected in 2018 from papers and reports of mangrove restoration, rehabilitation and reforestation projects in Vietnam as well as peer-reviewed articles in the Scopus database. Additionally, the Google Scholar database was used to expand the research results to include other available reports. The keywords mangrove AND restoration/ rehabilitation/reforestation AND Vietnam were used. For the Scopus database, results for these terms in the Article title, Abstract and Keywords fields yielded 31 references for the combination of restoration, rehabilitation and reforestation searches. To narrow the research for Google Scholar, we only used the above keywords for "title". This resulted in 50 references. The results of these searches are summarised in Table 1 .

Research results from the Scopus and Google Scholar databases for both peer-reviewed papers and related reports on mangrove restoration/rehabilitation and reforestation showed a limited array of outputs relevant to mangrove restoration. Therefore, we used all available references, including those related to reforestation, in this paper.

Additional project documents were not indexed in either Scopus or Google Scholar. We also collected grey data from libraries in Vietnam such as the Vietnamese Academy of Forest Sciences, Mangrove Ecosystems Research Division (Research Institute for Natural Resources and Environmental Studies, Vietnam National University-Hanoi), Ministry of Agriculture and Rural Development (MARD) and Ministry of Natural Resources and Environment (MONRE). We also 
Table 1 Number of research outputs on mangrove restoration

\begin{tabular}{llllll}
\hline Source & \multicolumn{2}{l}{ Preliminary search } & & After removing duplicates \\
\cline { 2 - 5 } & $\begin{array}{l}\text { "Mangrove" AND Vietnam } \\
\text { AND Restoration }\end{array}$ & $\begin{array}{l}\text { "Mangrove" AND Vietnam } \\
\text { AND Reforestation }\end{array}$ & $\begin{array}{l}\text { "Mangrove" AND Vietnam } \\
\text { AND Rehabilitation }\end{array}$ & Total \\
\hline Scopus & 16 & 7 & 8 & 31 & 50 \\
Google Scholar & 22 & 9 & 11 & 42 & 73 \\
Total & 38 & 16 & 19 & 73 \\
\hline
\end{tabular}

consulted with many mangrove experts in Vietnam to gather unpublished information on mangrove reforestation and restoration in Vietnam.

\subsection{Mangrove status and deforestation}

\subsubsection{Mangrove distribution}

The climatic, hydrographic and topographic characteristics of coastal areas strongly influence mangrove distribution in Vietnam. The mangroves in Vietnam are divided into 4 zones, namely Northeast coast (zone I), Northern delta (zone II), Central coast (Zone III) and Southern delta (zone IV) (Hong and San 1993) (Fig. 1). Covering the coastal region of southern Vietnam, zone IV provides the most favourable environmental conditions for mangrove development (Hong and San 1993). Every year, this zone receives alluvium and fresh water from the Cuu Long and Dong Nai river systems. Additionally, it has been less impacted by storms than the other three zones. With many sunny days and high radiation, zone IV supports the highest rates of growth of mangrove species (Hong and San 1993) and has nearly $80 \%$ of the total mangrove area in Vietnam (MARD 2014). In contrast, zone III is strongly impacted by natural disasters such as storms and king tides, hence mangrove areas have low growth rates and are affected by these events, and thus contribute about $1.5 \%$ of the total national mangrove area (MARD 2014). Although zone II is a net sink of nutrients (Wösten et al. 2003), this region is also impacted by natural disasters (Hong and San 1993). The proportion of mangrove areas in this zone is only $8.4 \%$ (MARD 2014). Zone I has the most complex environmental conditions compared with the other zones because the coastal mudflats are protected from storm damage by many islands. However, due to the northeast monsoon, sudden drops in temperature can strongly reduce the growth and development of mangroves (Hong and San 1993). Mangroves in zone I constitute about $10 \%$ of the total national mangrove area (MARD 2014).

\subsubsection{Mangrove deforestation}

Similar to other countries in Southeast Asia, Vietnam's mangroves have experienced rapid and large-scale conversion to agriculture and aquaculture (Richards and Friess 2016). The first record of mangrove deforestation was in 1916 with the removal of $549,478 \mathrm{~m}^{3}$ of fuel wood in Cochinchine (Joffre 2010). According to Joffre (2010), the use of mangrove products in Ca Mau province increased greatly from 1932 to 1941 and the greatest extraction was in 1940 (Fig. 2).

There was a notable reduction in the exploitation of mangrove forests in the Mekong Delta (Zone IV) during the middle of the Second Indochina War (1961-1975) as a result of extensive application of defoliants (Westing 1983). Approximately $36 \%$ (equivalent to 104,939 ha) of the mangrove area in the region was destroyed due to heavy defoliation. Rung Sat and Ca Mau Cape were the most impacted with about $57 \%$ of the overall surface area and $52 \%$ of dense mangroves, respectively, being destroyed (Hong and San 1993).

In 1986, Vietnam launched the Doi Moi Renovation which encouraged the development of trade liberalization and export growth, including planned and unplanned responses of the domestic agricultural sector to global markets. This led to large-scale conversion of mangrove forests to shrimp farms, especially in southern Vietnam (Zone IV) (Hong and San 1993; McNally et al. 2011). Between 1980 and 1987, the area of shrimp farming in Minh Hai province (currently known as $\mathrm{Ca} \mathrm{Mau}$ and Bac Lieu provinces) in zone IV increased from 3000 to 40,000 ha (De Graaf and Xuan 1998) and reached 60,000 ha by 1992 (De Graaf and Xuan 1998) (Fig. 3). By 1993, the area of shrimp ponds in this province had increased nearly 20 times compared with 1980 (Hong 1996). In northern Vietnam, mangroves were still being removed in 2001 for shrimp farming while large efforts were being made to restore mangroves as sea dike protection and for the provision of ecosystem services for local communities (Lebel et al. 2002). From satellite imagery, Beland et al. (2006) showed that about $63 \%$ of the original mangroves that were present in 1986 in Giao Thuy district, Nam Dinh province were partially or entirely converted to shrimp ponds by 2001 . The total area of shrimp ponds in Vietnam in 1994 was 200,000 ha, second to Indonesia (Tobey et al. 1998) which has the largest area of mangroves in the world (FAO 2018). Overall, from 1980 to 2015, there has been a dramatic increase in brackishwater habitats for aquaculture cultivation and marine production in Vietnam, increasing production from 3960 to $793,176 \mathrm{t}$ and 3240 to 213,968 t, respectively (FAO 2018) (Fig. 4). 
Fig. 1 Distribution of mangroves in Vietnam in 2013 (data source: MARD (2014)

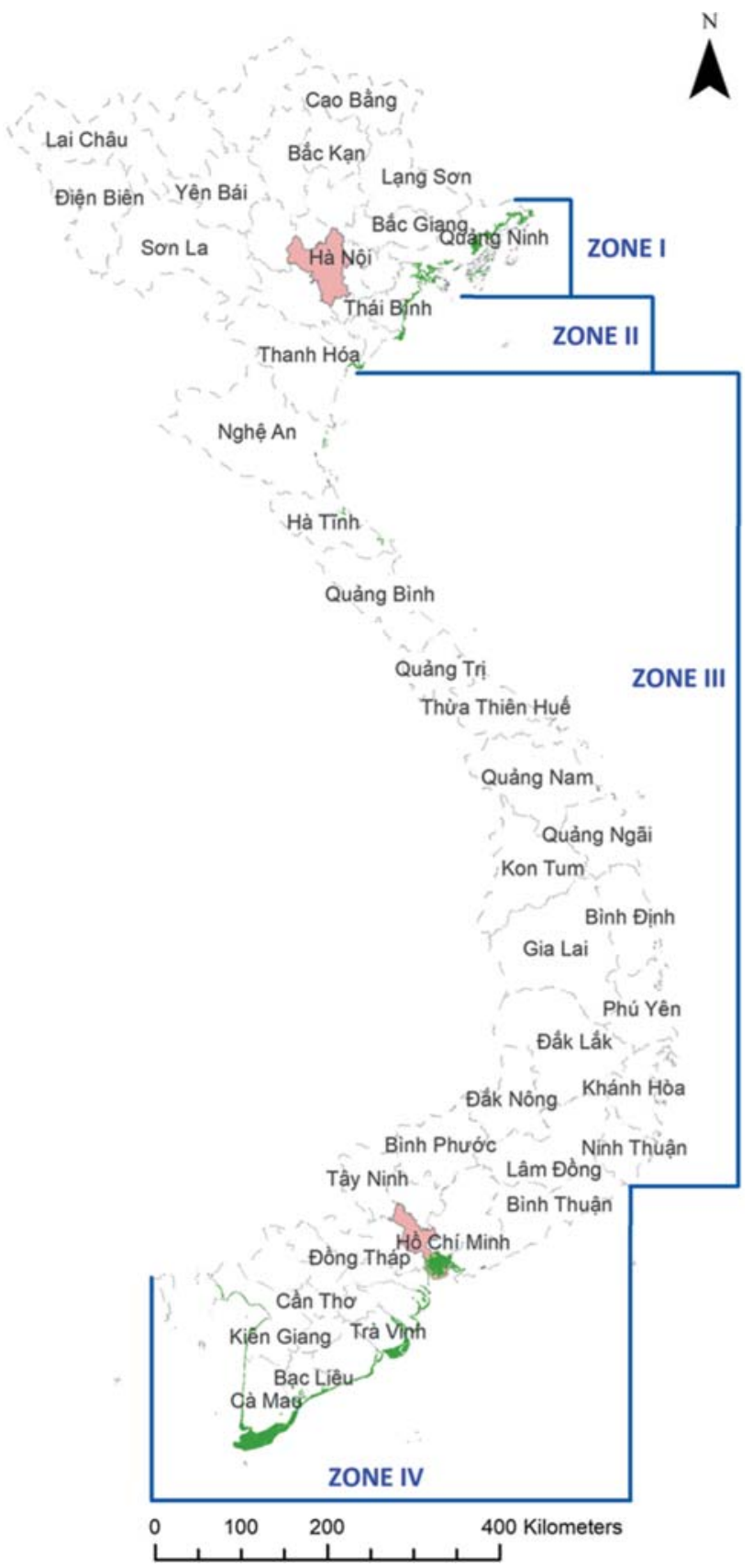

Zone I (North-east coast from Ngoc Cape to Do Son Cape): 20,486 ha

Zone II (Northern delta from Do Son Cape to Lach Truong River): 14,127 ha

Zone III (Central coast from Lach Truong to Vung Tau Cape): 2,508 ha
In addition to the conversion of mangroves to aquaculture, other activities such as land reclamation for agricultural expansion, infrastructure development, urbanization and industry and tourism development have further contributed to the decline of mangroves in Vietnam (Hawkins et al. 2010). More recently, the development of clam farming on mudflats, timber and fuel-wood harvesting, fishing and shellfish collection have become additional drivers for mangrove loss (Hawkins et al. 2010; McNally et al. 2011). Additionally, the dumping of urban solid waste in coastal areas (approximately 14.03 million tons annually) and oil spill accidents (from 1989 to 2009 there were 200 oil spills) (Hoi 2012) have significantly contributed to mangrove degradation in recent decades (Hawkins et al. 2010). Mangrove loss in Vietnam is also attributed to coastal erosion. There are 263 erosion sites represented for all coastal provinces in Zone III (from Thanh Hoa to Binh Thuan province), of which the smallest site covers 1.4 ha and the largest site covers 262.8 ha (Tien and Van $\mathrm{Cu} 2005$ ). Although there are no data available on the total mangrove loss resulting from coastal erosion, it is evident that coastal erosion is an important cause of mangrove decrease in Vietnam. Additionally, the coastal zone of Vietnam is subjected to substantial impacts from waves and storms (Cat et al. 2006). Depending on the coastal topography, sea water can 


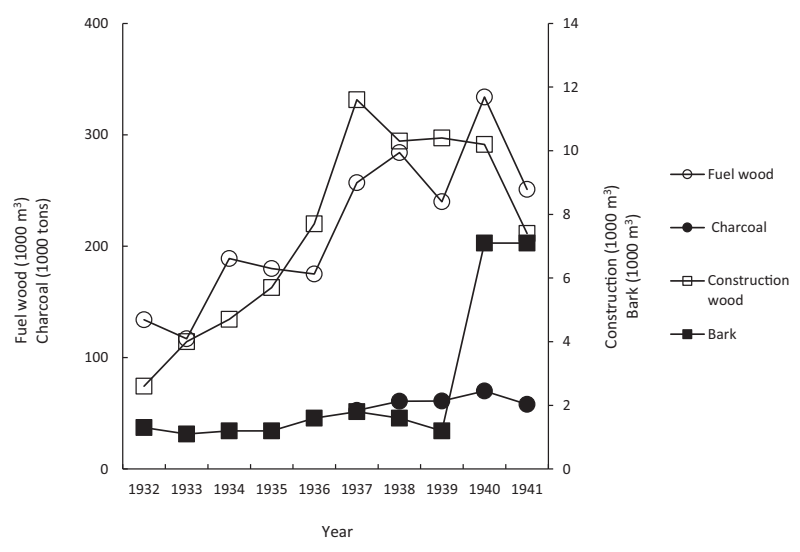

Fig. 2 Mangrove products used in Ca Mau from 1932 to 1941 (redrawn from Joffre (2010)

invade from 1 to $3 \mathrm{~km}$ inland, with depths of 4 to $5 \mathrm{~m}$ (Cat et al. 2006).

All of the abovementioned impacts have appreciably contributed to a reduction in the mangrove area with nearly $60 \%$ of the total area being lost since 1943 (Fig. 5). In terms of mangrove changes in the four Zones, nearly 84,000 ha of mangroves were lost over 30 years from 1983 to 2013 (Table 2). The area of mangroves fell in three out of four zones, of which zone IV had the largest decrease in area. The reduction in area of mangroves would have been greater if Vietnam had not implemented reforestation or restoration programs since 1975 under State and non-government organization sponsorships (see Sect. 4).

\subsubsection{Future threats}

The current issues of mangrove deforestation in Vietnam are likely to be exacerbated by future impacts of climate change (Ward et al. 2016). It is predicted that by the end of the twentyfirst century, average temperatures will likely increase by $3-$ $4{ }^{\circ} \mathrm{C}$ compared with the baseline scenario of 1986-2005 (Thuc et al. 2016). Increased surface temperature may affect

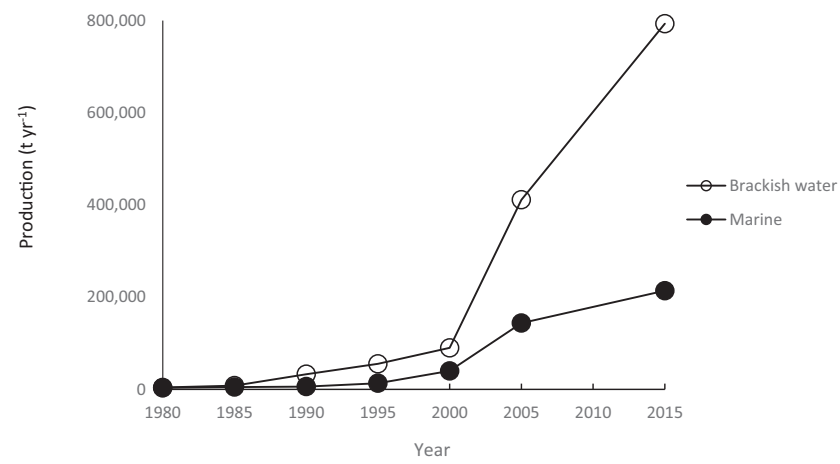

Fig. 4 Aquaculture production in Vietnam since $1980\left(\mathrm{t} \mathrm{yr}^{-1}\right)$ (Redrawn from FAO (2018)

mangroves through changes in species composition and phenology, increases in mangrove productivity if the temperature is below the species' upper threshold and expansion of mangrove ranges to higher latitudes (Field 1995). Furthermore, annual rainfall may increase by $5-15 \%$ in some regions by the mid-century and may reach $20 \%$ in some coastal provinces (Thuc et al. 2016). Additionally, precipitation in the dry season is likely to decrease in some regions of Vietnam (Thuc et al. 2016). A decrease in rainfall in the dry season together with increased evaporation are expected to increase salinity leading to a decrease in primary productivity, growth rate and seedling survival (Field 1995). Like temperature, these projected changes in precipitation may affect mangrove structure and growth, as well as their distribution (Ellison 2000).

Of all the outcomes from changes in the atmosphere's composition and alterations to land surfaces, relative sea-level rise may be the greatest threat (Field 1995; Lovelock and Ellison 2007). Alongi (2008) identified Vietnam as one of the most vulnerable regions to future sea level rise because of the low tidal range and lower sediment output except for the Mekong and Red River Deltas. The projected increases in sea level will likely impact significantly on future mangrove area and health (Ellison 2000; Gilman et al. 2007). If sea level rises by $1 \mathrm{~m}$,
Fig. 3 Change in cultured shrimp production and mangrove area from 1976 to 1992 in Minh Hai province (Redrawn from De Graaf and Xuan (1998)

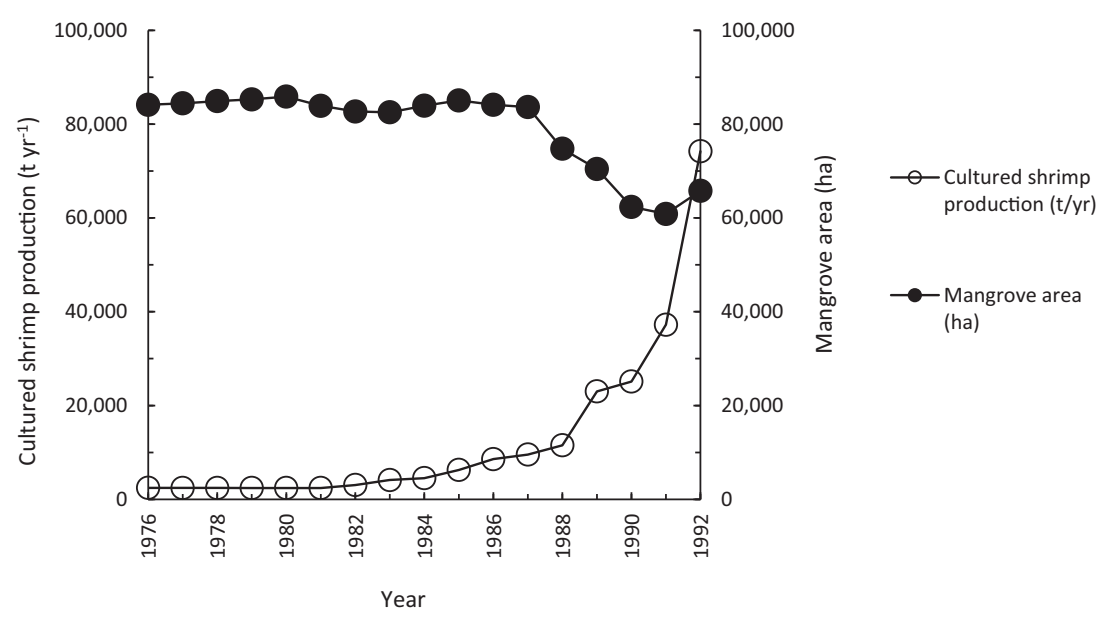




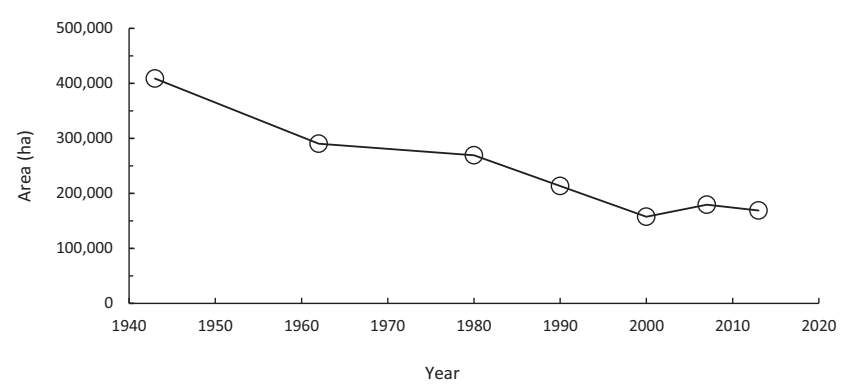

Fig. 5 Change in mangrove area from 1943 to 2013 in Vietnam (FAO 2007; Powell et al. 2011a; MARD 2014)

about 40,500 ha (equivalent to $27.2 \%$ ) of mangroves in Vietnam will be inundated (Carew-Reid 2008). Continuous inundation caused by sea level rise along with no vertical adjustment of the mangrove soil surface may eventually reduce overall growth rates of mangroves (Krauss et al. 2014) and even cause death. This situation will be worsened with changes in coastal sedimentation (Ward et al. 2016). Due to river modification and damming, the coastal zones of Vietnam are facing a significant reduction in fluvial sedimentation. For example, the Red River Delta has experienced a $76 \%$ reduction in annual sediment yield (Gupta et al. 2012) leading to a sediment deficit in downstream coastal mangroves. Surface elevation and sediment deficits and predicted sea level rise will impact mangrove inundation, agricultural land and coastal human settlements (Le et al. 2007).

Higher production targets for the aquaculture industry and the more general development of sea and brackish water aquaculture will continue to hasten mangrove deforestation in the future (McNally et al. 2011). Although the total area of shrimp farming in the Mekong River Delta region is expected to be similar in 2020 as in 2014 (about 650,000 ha), Vietnam's Ministry of Agricultural and Rural Development has plans to increase this to 670,000 ha by 2030 (MARD 2015). It is not clear in MARD's plan which types of land use are scheduled to be converted to aquaculture, but it may represent a further threat to mangroves in the region. Other future threats, including high intensity coastal erosion (Cat et al. 2006; Mackenzie et al. 2016), industrial development, population

Table 2 Change in area of mangroves (ha) from 1983 to 2013

\begin{tabular}{llll}
\hline Location & \multicolumn{2}{l}{ Mangrove area (ha) } \\
\cline { 2 - 4 } & 1983 & 2013 & Change \\
\hline Zone I & 39,400 & 20,486 & $-18,914$ \\
Zone II & 7000 & 14,127 & 7127 \\
Zone III & 14,300 & 2508 & $-11,792$ \\
Zone IV & 191,800 & 131,568 & $-60,232$ \\
Total & 252,500 & 168,689 & $-83,811$ \\
\hline
\end{tabular}

Sources: Hong and San 1993; MARD 2014 increase and residential solid waste, will also impact directly and indirectly on mangrove deforestation and degradation in Vietnam.

\subsection{Mangrove restoration in Vietnam}

\subsubsection{Overview of mangrove restoration activities in Vietnam}

There are clear motivations for the development of mangrove restoration programs and projects in Vietnam, including (1) historical experience of significant loss and damage as a result of coastal disasters and conflict; (2) a legal requirement to implement mangrove restoration and to protect inland properties and economic production activities; and (3) clear ecosystem and economic benefits provided from mangrove restoration activities (Buckingham and Hanson 2015).

Mangrove restoration efforts in Vietnam have a long history and can be divided into three periods: (1) the post-war period (from 1975 to 1980), (2) a second period (from 1981 to 1990) and (3) from 1990 to the present.

In the first period, mangrove restoration projects and programs were mostly implemented in zone IV in order to recover destroyed mangrove forests after the Second Indochina War (Tuan et al. 2010). The total mangrove area planted in this period was 52,450 ha (Table 3 ). However, mangrove restoration in this period failed in many places as a result of applying poor silvicultural techniques (Hong 2008). There are, however, no recorded data on the rate of mangrove failure or success under these restoration projects.

From 1981 to 1990 , mangrove restoration programs continued to be concentrated in zone IV, with some small-scale projects implemented in zones II and III. In this decade, most of the projects were State-funded. The total restored area was 52,913 ha (Tuan et al. 2010) (Table 3).

In the third period from 1990 up to the present, many restoration programs and projects were implemented under State sponsorship. In 1992, the government started a large mangrove reforestation program as a part of the reforestation of bare land and hills under Decision No. 327. More than 52,000 ha of mangroves were replanted under this program (Hong 2008). Following this program, the Five Million Hectares Reforestation Project was implemented under Decision No. 661/ND-TTg dated 29 July 1998. Under this program, mangrove restoration actions were carried out in almost all coastal provinces from 1998 to 2010, but there are no published reports on the success of this effort. From 2011 to 2020, under the National Target Program, the Forest Protection and Development Plan and other related programs, 113 projects were implemented targeting restoration efforts across 48,096 ha (Table 4).

Apart from state-funded projects, mangroves in Vietnam also have been restored with support from international NGOs (Table 5). From 1990 to date, the total restored 
Table. 3 Mangrove reforestation and restoration efforts over the period from 1975 to 1990 under State sponsorship

\begin{tabular}{llll}
\hline Province & Location & Treated area 1975-1980 (ha) & Treated area period 1981-1990 (ha) \\
\hline Hai Phong & Zone II & & 234 \\
Thai Binh & Zone II & & 1399 \\
Nghe An & Zone III & & 563 \\
Ha Tinh & Zone III & & 46 \\
Ba Ria-Vung Tau & Zone IV & & 3615 \\
Dong Nai & Zone IV & 4100 & \\
Ho Chi Minh city & Zone IV & 6240 & 20,636 \\
Tien Giang & Zone IV & & 463 \\
Ben Tre & Zone IV & 10,470 & 1200 \\
Tra Vinh & Zone IV & 3990 & 4137 \\
Soc Trang & Zone IV & 1750 & 1404 \\
Minh Hai* & Zone IV & 25,900 & \\
Bac Lieu & Zone IV & & 716 \\
Ca Mau & Zone IV & & 18,500 \\
Total & Zone IV & 52,450 & 52,913 \\
\hline
\end{tabular}

*Minh Hai province was later separated into Bac Lieu and Ca Mau provinces (source: Tuan, 2010) mangrove area from these projects is 43,750 ha and in the next 5 years, a further 19,000 ha of mangroves are expected to be restored (Table 5). Twenty major projects have been implemented across most coastal provinces in Vietnam. The projects range in scope from small to large. Of the large projects, the "Mangrove Plantation and Disaster Risk Reduction" has spanned two decades. This project was established first in Thai Binh province from 1994 to 1996. Later (1997-2010), it was extended to 8 provinces in the Northeast coast and Northern Delta regions (Red Cross 2012).

Most of these projects were implemented in several provinces and cover areas greater than 500 ha except for four projects which have restoration areas lower than 100 ha (Fig. 6). These four projects were mainly implemented in a single province and lack clear monitoring and assessment outcomes.

To mitigate against tropical typhoons and adapt to climate change, mangrove restoration projects have been concentrated in northern and central Vietnam (Thu and Populus 2007) in zones II and III. Recently, mangrove restoration in southern Vietnam (Zone IV), especially the Mekong River Delta, has received more impetus due to concern about climate change and sea level rise (Thuc et al. 2016).

\subsubsection{Uncertainty around the area of successful mangrove restoration in Vietnam}

Mangrove restoration projects funded by international NGOs began in the 1990s (Fig. 7). Before the 1990s, most mangrove restoration activities were implemented in zone IV to recover defoliated mangrove areas after the Vietnam War. From 1990, restoration activities have been distributed among the four zones (Fig. 7).

Over the period from 1975 to the present, data synthesised from mangrove restoration programs funded by either the state and/or NGOs showed that the reported areas of mangrove restoration projects in Vietnam reached about 197,000 ha (Fig. 7). In the period 1980-2013, however, the total mangrove area reduced from 269,150 to 168,688 ha (Fig. 5), indicating that not all of the restoration projects were successful.

It is clear that mangrove restoration projects and programs have played a significant role in maintaining mangrove forest cover in Vietnam. While there are successful examples of mangrove restoration, it is difficult to estimate the proportion of restored mangrove areas that exist over the total area of mangroves due to the lack of monitoring and assessment of survival rates in these programs. Although there is a provincial forest inventory every year and a national forest inventory every 5 years, and the mangrove area is reported, there are a lack of data on the increase in mangrove area from restoration projects. In the future, integration of mangrove restoration projects into Vietnam's national inventory program, will provide an opportunity to quantify more accurately the real contribution of mangrove restoration projects.

\subsection{Objectives of mangrove restoration}

There have been various historical objectives for mangrove restoration in Vietnam. Before 1982, the primary goal of mangrove restoration was reforestation for silviculture (Ellison 2000). Other purposes, such as coastal protection and environmental mitigation, were listed as supporting objectives (Schmitt and Duke 2014). After 1982, mangrove restoration 


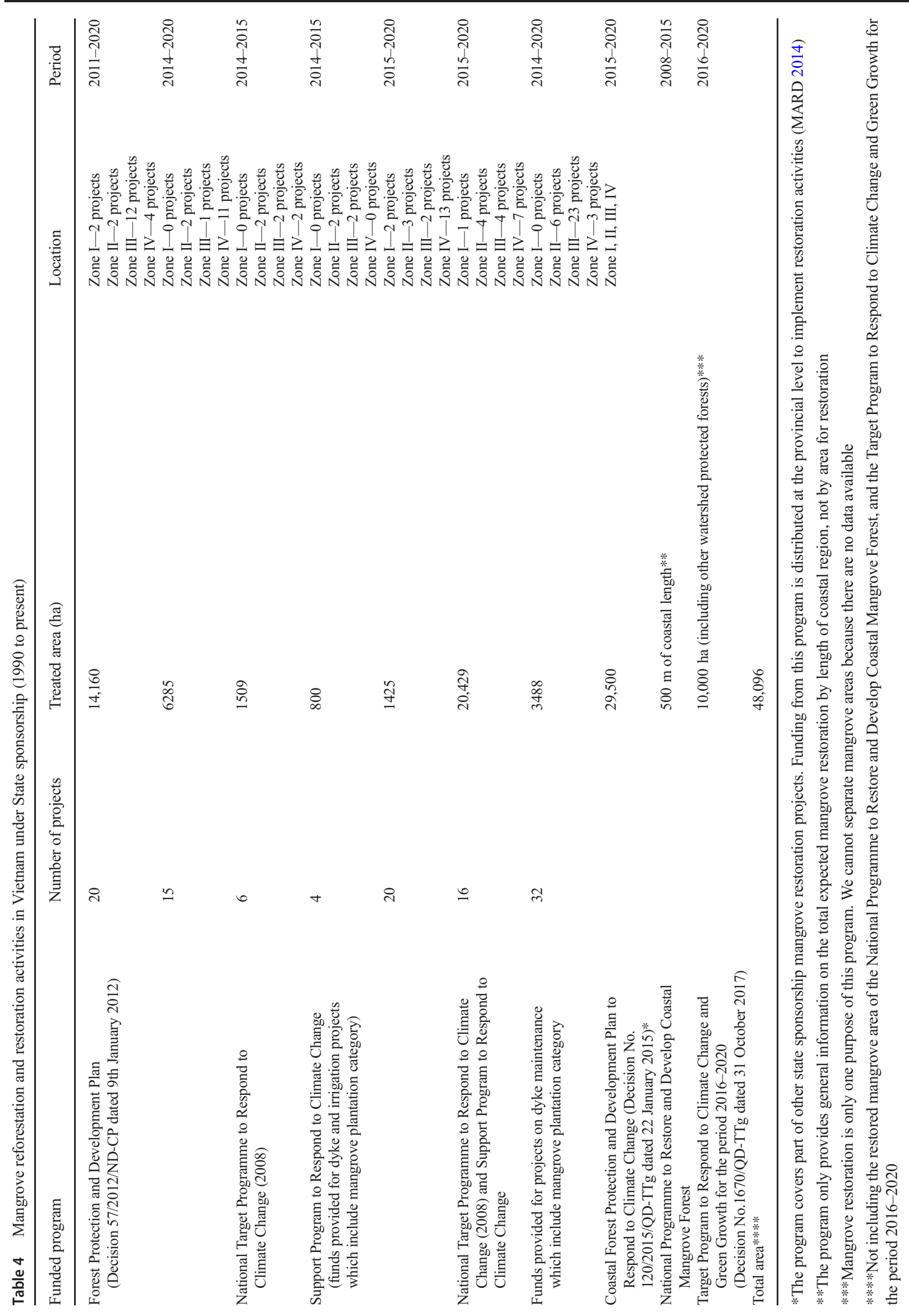




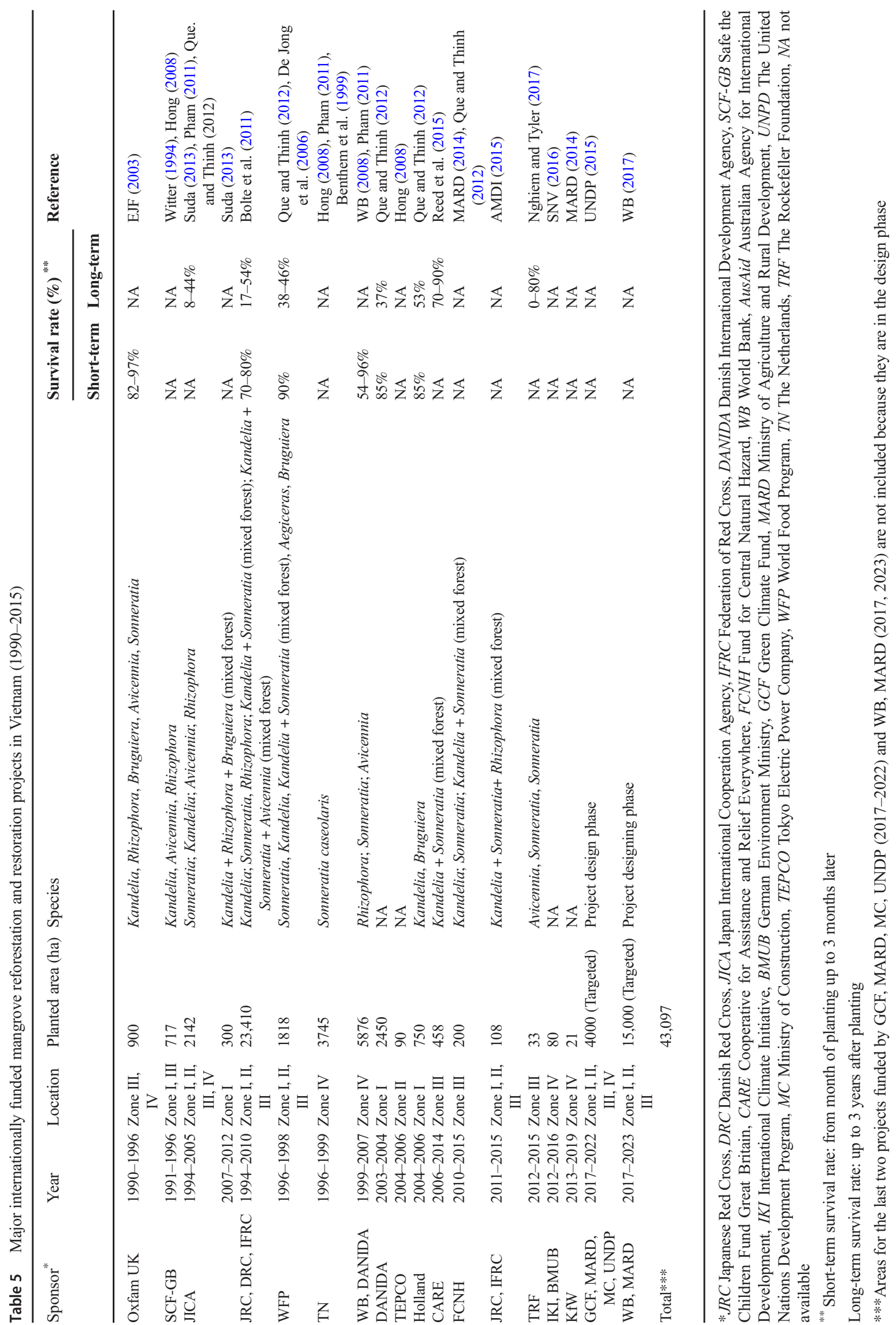

INRAC פ Springst 
Fig. 6 Distribution of mangrove restoration projects in Vietnam carried out with external funding from 1990 to 2019

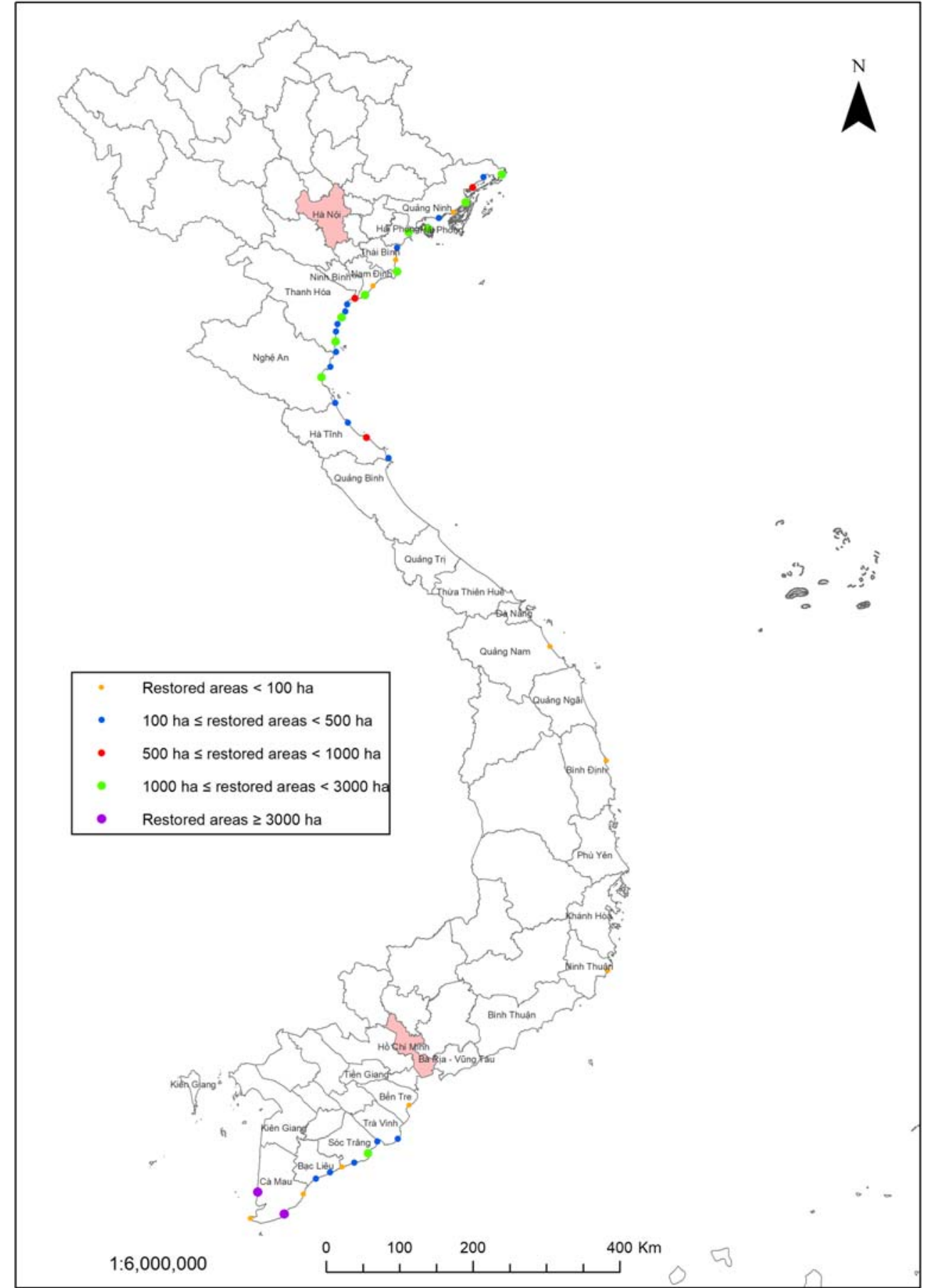

objectives focused on sustainable utilization, animal habitats, inshore food sources and the provision of community livelihoods (Stubbs and Saenger 2002). Similar to other countries, objectives of mangrove restoration in Vietnam are mixed and complex. We identified the objectives of mangrove restoration projects in Vietnam following the results of Ellison (2000) who classified objectives of mangrove restoration projects worldwide. In his research, mangrove restoration objectives were divided into five groups, namely forest products, fisheries, coastal protection and stabilization, climate mitigation and adaptation and ecosystem preservation.

It is clear that the objectives of mangrove restoration vary depending on sources of damage to mangroves. Results in Table 6 show that around half of all mangrove restoration projects in Vietnam focused on coastal protection and stabilization, especially in zones II and III which are more vulnerable to natural disasters (Buckingham and Hanson 2015). By contrast, mangrove restoration efforts in zone IV (southern 


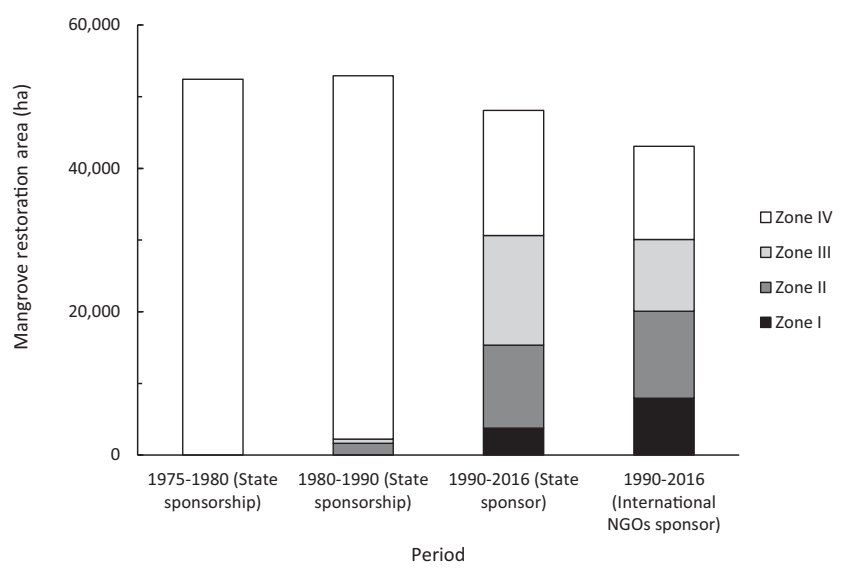

Fig. 7 Mangrove restoration areas funded by State and international NGOs in Vietnam from 1975 to present

Vietnam) were aimed at poverty alleviation and livelihood diversification (Buckingham and Hanson 2015) in a region which is less vulnerable to typhoons and storms (Takagi et al. 2014).

Recently, climate change mitigation and adaptation to sea level rise have become important objectives (McLeod and Salm 2006; Krauss et al. 2014). From the middle of the 2000s, all mangrove restoration projects have set their main or supplemental objectives on climate change mitigation and adaptation (Table 6). In contrast to a stand-alone and hard measure approach, such as building dikes to cope with natural disasters, mangrove restoration has recently been promoted as a "no regrets measure" and "precautionary" approach to climate change adaptation and mitigation, a "win-win" solution to solve present multi-sectoral vulnerabilities and future risks (Powell et al. 2011a). Importantly, climate change mitigation is being dealt with globally and may result in more international sources of finance for mangrove restoration.

\subsection{The contribution of mangrove restoration activities}

Generally, mangrove restoration projects (including state sponsored and international projects) implemented in Vietnam have contributed to an increase in mangrove areas. In this paper, it is estimated that from 1975 to 2018, about 197,000 ha of mangroves were planted in Vietnam. However, as discussed, since there are no assessments of survival rates after restoration projects are finished, it is not clear how this has contributed to the current total mangrove cover in Vietnam. Although mangrove restoration projects are also considered to have brought co-benefits, such as enhancement of biodiversity in Can Gio Biosphere Reserve (Ho Chi Minh City) and Ca Mau National Park; the expansion of alluvial soils and reduced soil erosion in Con Ngan, Con Lu of Xuan Thuy Ramsar, Con Trong and Con Ngoai of Ca Mau Cape, and hindered salt intrusion (Hong 2008) there is little or no formal reporting of these attributes.

Table 6 Declared objectives of mangrove restoration projects in Vietnam. Dark shading — main goals; light shading — supplementary goals of project

\begin{tabular}{|c|c|c|c|c|c|c|c|}
\hline \multirow[t]{2}{*}{ Sponsor } & \multirow[t]{2}{*}{ Period } & \multicolumn{5}{|c|}{ Restoration objective } & \multirow[t]{2}{*}{ Reference } \\
\hline & & $\begin{array}{c}\text { Forest } \\
\text { products }\end{array}$ & Fisheries & $\begin{array}{c}\text { Coastal } \\
\text { protection } \\
\text { and } \\
\text { stabilization }\end{array}$ & $\begin{array}{c}\text { Mitigation } \\
\text { and } \\
\text { adaptation }\end{array}$ & $\begin{array}{l}\text { Ecosystem } \\
\text { restoration }\end{array}$ & \\
\hline Oxfam UK & $1990-1996$ & & & & & & EJF (2003) \\
\hline SCF - GB & 1991-1996 & & & & & & Witter (1994) \\
\hline JICA & 1994-2005 & & & & & & Suda (2013) \\
\hline JRC, DRC & $1994-2010$ & & & & & & Bolte et al. (2011) \\
\hline $\mathrm{TN}$ & 1996-1999 & & & & & & Benthem et al. (1999) \\
\hline WB, DANIDA & $1999-2007$ & & & & & & WB (2008) \\
\hline DANIDA & $2003-2004$ & & & & & & Lai (2008) \\
\hline CARE & $2006-2014$ & & & & & & Reed et al. (2015) \\
\hline JICA & $2007-2012$ & & & & & & Suda (2013) \\
\hline $\mathrm{FCNH}$ & $2010-2015$ & & & & & & Que and Thinh (2012) \\
\hline JRC, IFRC & $2011-2015$ & & & & & & AMDI (2015) \\
\hline $\begin{array}{l}\text { TRF } \\
\text { IKI, BMUB }\end{array}$ & $\begin{array}{l}2012-2015 \\
2012-2016\end{array}$ & & & & & & $\begin{array}{l}\text { Nghiem and Tyler (2017) } \\
\text { SNV (2016) }\end{array}$ \\
\hline KfW & 2013-2019 & & & & & & MARD (2014) \\
\hline $\begin{array}{l}\text { GCF, MARD, MC, } \\
\text { UNDP }\end{array}$ & $2017-2022$ & & & & & & UNDP (2015) \\
\hline WB, MARD & $2017-2023$ & & & & & & WB (2017) \\
\hline
\end{tabular}


Due to mangrove restoration programs, the north and central parts of Vietnam are considered to have experienced disaster risk reduction (Powell et al. 2011a). In Kien Thuy District, Thai Binh province, during typhoon Damrey in 2005 , the protective benefits of restored mangroves, funded by the Red Cross, substantially contributed to wave reduction from 0.5 to $4 \mathrm{~m}$ in height. Mangroves are usually planted between the sea and sea dykes and by mitigating wave intensity protect the dikes (Osbeck et al. 2011). In contrast, without mangroves, disaster repair costs were around US \$1.2 million in Giao Hai and Giao Long communes (Buckingham and Hanson 2015).

In southern Vietnam, mangrove restoration activities have addressed poverty alleviation and livelihood diversification for food and income generation (Buckingham and Hanson 2015). These projects have brought opportunities for nearly 8000 households as they receive land leases and benefit from the development of infrastructure, such as schools, roads and health care (Powell et al. 2011b). Economic values generated from 150 ha of restored mangroves were estimated to be higher than investment in agriculture and were more than USD 1.1 million (priced in 2010) compared with USD 0.55 million (priced in 2010) over a 22-year period at a discount rate of $10 \%$ (Tuan and Tinh 2013).

\section{Issues associated with current mangrove restoration projects}

\subsection{Monitoring and evaluation}

According to Le et al. (2012), to assess successful restoration projects in developing countries, it is necessary to evaluate four main indicators, namely (1) the survival rate of planted trees measured within months of planting to the third year; (2) successful forest growth comprising tree growth, stand density and stem form of timber trees; (3) environmental success, including vegetation structure, ecosystem function and species biodiversity; and (4) socioeconomic success meaning that the project can provide local income or local employment opportunities.

However, there is usually a lack of long-term assessment for many restoration efforts. Only $30 \%$ of the listed project evaluation reports in this paper have cited seedling survival rates and only $35 \%$ had long-term (>3 months after transplanting) survival rate assessment (Table 5). Surprisingly, only $20 \%$ of the projects assessed both shortterm and long-term survival rates. This is a consequence of weak monitoring plans in the original proposal documents possibly due to the lack of finance available to invest in post hoc monitoring and evaluation. In some reports where survival rate data are provided, the method of data collection is not specified, and the data are not statistically analysed.
Projects with very high survival rates (from 70 to $90 \%$ in the first 3-month assessment), are often described as successful. However, survival rates in the long-term range from 0 to $90 \%$, with most restoration projects achieving long-term survival rates from 30 to $50 \%$. In some projects, restored mangrove forests completely died, such as a mangrove restoration project conducted in Quy Nhon province (Que and Thinh 2012; Nghiem and Tyler 2017). Restoration projects can be considered successful if they survive, grow and realise full environmental and socioeconomic benefits to local people (Reay and Norton 1999). Primavera and Esteban (2008) suggested that to achieve biological success in a restoration project, it is necessary to have a monitoring plan at 3 and 6 months, as well as at 1 , 3 and 5 years after planting because, for most mangrove species, reproduction commences between 3 to 5 years.

\subsection{Site and species selection}

Bosire et al. (2008) present a systematic 10-step approach for mangrove restoration. A key component is to understand the stressors that initially caused the loss of the mangroves, the degree of disruption and determining whether those stresses can be alleviated and involvement of the local community. In some cases, mangroves may recover without intervention, in others the stressors may remain and replanting will be pointless. For example, restoration of mangroves affected by herbicides will be a totally different proposition to restoration of areas formerly used for prawn production.

Globally, there are many examples in which mangrove restoration has failed because hydrology was not considered. Hydrologic impairment causes changes in hydroperiod, soil collapse due to mangrove death, hypersalinity and very negative redox potentials (Dijksma et al. 2010). Similarly, the soil may have been degraded in the period since the loss of the mangroves, and thus present quite different conditions for restoration, compared with what previously existed under the mangroves. Site evaluation thus requires characterization of hydrologic regimes before starting site works which could include hydrologic restoration, and then selection of species.

There is controversy on the success of mangrove restoration in terms of species selection. Some advocate that using only one species for mangrove restoration results in rapid development of mangroves as well as the ability to restore several ecosystem structures and functions (Ferreira et al. 2015). Restoration is desirable from an economic perspective when benefits flow directly to local communities (Tri et al. 1998). For mangrove monoculture restoration, if including only indirect benefits, such as avoided maintenance cost of sea dike systems and coastal storm mitigation, the benefitcost ratio of a successful mangrove restoration in Nam Dinh province has been reported at 4.7 with a discount rate of $10 \%$ (Tri et al. 1998). However, even though monoculture mangrove restoration has been used as an example of mangrove 
restoration success, it does not fit the definition of ecological restoration (Lewis 2001). Ellison (2000) states that if mangrove restoration is undertaken with a single or few species, this method is just sufficient to be considered reforestation, but not for ecosystem restoration.

The genus Rhizophora has been widely selected in restoration projects (Ellison 2000). This genus has a worldwide distribution (Giri et al. 2011), and there has been much research on the growth of Rhizophora in Asia, including in planted stands (Clough et al. 2000). The widespread use of $R$. apiculata for mangrove restoration programs in the Mekong River Delta of Vietnam is understandable due to easy and efficient propagule collection and high economic value when selling wood. However, this species may not be suitable for restoration at all sites, especially on the seaward side of fully protected zones (Streever 1999). In the northern region of Vietnam, monocultures R. stylosa, Kandelia candel or Sonneratia caseolaris are most common. Although these monoculture species can maximise protection benefits in terms of wave height reduction, local residents have claimed that mangrove monocultures do not supply productive habitats for wild clams, crabs and fisheries (Osbeck et al. 2011). This may directly impact local livelihoods and the long-term success of mangrove restoration projects.

Selecting species unsuitable to site conditions also may lead to the failure of mangrove restoration projects (Lewis 2005). While salinity and soil conditions are often mentioned as important criteria, hydrology is usually not taken into account due to difficulties in assessment (Van Loon et al. 2016). For some sites with irregular micro-topography, such as Can Gio, it is necessary to develop a detailed hydrological site characterization (Dijksma et al. 2010). In some coastal provinces in northern Vietnam (zone II) that are strongly impacted by storms, planting Sonneratia, Avicennia and Aegiceras directly onto mudflats was largely unsuccessful because these taxa were exposed to strong winds and wave forces (Tri et al. 2001). Additionally, the cost of raising these taxa in nurseries and transplanting at the age of eight months old is relatively high which added to overall expenditure (Adger et al. 1997).

An additional consideration in species selection is taking into account the suitability of the chosen species given future projections of climate change. However, we did not find any consideration of this in the climate mitigation projects.

It is clear that formal site selection guidelines should be developed for mangrove projects in Vietnam, and other regions, particularly with the increased interest in "blue carbon" investment to mitigate climate change. This step, together with following protocols that consider every step in the restoration project, from the establishment of a baseline to the monitoring of the final restoration strategies, such as developed by Bosire et al. (2008) is likely to increase the success of projects as they will be established on the basis of known mangrove science.

\subsection{Long-term management problems}

One of the main reasons leading to the failure of mangrove restoration programs is the lack of incentives for long-term management. Mangrove restoration programs in northern Vietnam (zones I and II) usually achieve only a low level of success compared with the southern region (zone IV) as a result of the lack of long-term incentives for local communities. Even though making contracts with local communities to plant and protect mangrove plantations, the Red Cross restoration program was not able to achieve a high level of success because they did not provide incentives for local people to protect mangroves from human impacts, such as illegal cutting or grazing, when the program ended in 2006 (Powell et al. 2011a).

In contrast, mangrove restoration in zone IV has been more successful. An example is the mangrove restoration program in Can Gio, Ho Chi Minh City, funded by the Vietnamese government from 1987 to 1994. The Management Board of Ho Chi Minh City's Environmentally Protected Forests made 30 -year contracts with the forest protection workers and nearby households, provided rewards (allocating 3-5 ha of land for aquaculture or salt ponds) and other benefits (e.g. money to build a house on allocated land, boats for forest protection activities, loans for authorised fisheries production and forestry activities and technical training for activities such as shrimp farming) (Hong 2001). Although there was no assessment on the real benefits that local communities received from the restoration program, this approach highlights the importance of encouraging households in mangrove protection after planting. In northern Vietnam, the restoration project funded by CARE Australia and implemented in Da Loc commune was considered to be successful with a survival rate of 70-90\% over a 3-year period thanks to a community-based management approach that provided incentives for local residents during and after the restoration project (Kempinski and Cuc 2009).

Co-management is an emerging approach which engages local communities in long-term mangrove restoration projects. In this approach, government agencies share decision making, responsibility and accountability with local communities whose livelihoods depend on ecosystem services provided by mangroves (Schmitt and Duke 2014). Through participatory processes, resource users and local authorities negotiate a formal agreement on their respective management roles, responsibilities and rights and establish a pluralistic governance body (Borrini-Feyerabend et al. 2012). Mangrove comanagement in the Mekong Delta in Vietnam has been shown to be an effective way of maintaining and enhancing the protection function of the mangrove forest, to provide livelihood for local communities and to contribute to better governance of natural resources (Schmitt 2012). Livelihood improvement can be further enhanced by setting up integrated mangrove 
aquaculture systems such as mud crab fattening in mangrove pens and cages, mixed shrimp-mangrove-crab-cockle systems or integrated mangrove fish or shrimp farms (Macintosh and Ashton 2003).

Le et al. (2012) noted that a successful restoration program needs to ensure strong community participation in all activities, including planning, implementation, management and monitoring. The lack of community involvement in any of these activities may lead to the failure of restoration projects. As a result of a lack of communication at the reporting stage between the community and the mangrove project agency in Hon Dat district, Kien Giang province, after 2 project-years the survival rate of restored mangroves was only $20 \%$ compared with $70-90 \%$ where there was good communication (Nguyen et al. 2016).

\subsection{Opportunities for mangrove restoration projects in the context of current international agreements on climate change}

Mangroves are considered one of the most carbon-rich ecosystems in the tropical regions and extraordinarily high in comparison with mean $\mathrm{C}$ storage of other major forest domains (Alongi 2012). Restoration projects can thus contribute to carbon emission reduction strategies (Rivera-Monroy et al. 2017), and mangrove restoration has been integrated into many international agreements. The contribution of forest restoration to greenhouse gas emission reduction was first recognised under the United Nations Framework Convention on Climate Change (UNFCCC) and in the Vietnamese context, the Clean Development Mechanism (CDM). There has only been one forestry CDM project in Vietnam implemented at Cao Phong district, Hoa Binh province aimed at restoring a total area of 365 ha of forests (Broadhead 2011).

Mangrove restoration efforts are also incorporated into other UNFCCC forest mechanisms, for example Reducing Emissions from Deforestation and Forest Degradation (REDD+) which is concerned with the role of conservation, sustainable management of forests and enhancement of forest carbon stocks in developing countries as part of Land Use, Land Use Change and Forestry (LULUCF) activities.

Recently, with the adoption of the Paris Agreement, twenty-nine Parties including Vietnam have committed to using mangrove restoration as a climate mitigation activity as part of their Nationally Determined Contributions (NDCs) (Herr and Landis 2016). Of these Parties, 39\% are also seeking climate change adaptation benefits (Herr and Landis 2016).

There appears to be a significant opportunity to include blue carbon into the mitigation section of the country NDCs in the future (Herr and Landis 2016). However, based on the Vietnamese experience reported in this paper it is crucial that robust monitoring and reporting protocols are developed and implemented, and co-benefits and trade-offs are fully considered.

According to Alexander et al. (2011), a successful mangrove restoration activity which integrates ecological functions and other social, economic and cultural benefits has the potential to provide a range of co-benefits. Markets for these co-benefits may develop (e.g. biodiversity, marine habitat, coastal protection), and these will require measurement and reporting of attributes in restoration projects that are not currently considered. Certainly, in this new context of payment for different environmental services, reporting of mangrove success will have to consider more than just the areas restored and their survival rate.

In Vietnam's Intended Nationally Determined Contributions (INDCs), mangrove plantations were proposed as one of the important options for climate change mitigation. It was suggested that if 30,000 ha of mangroves are planted, total greenhouse gas mitigation potential of approximately $4.41 \mathrm{Mt} \mathrm{CO}_{2} \mathrm{e}$ will be achieved for the 10-year period from 2021 to 2030 (Hieu et al. 2016). Recent research on $\mathrm{C}$ stocks following mangrove restoration in the Mekong River Delta of Vietnam shows that there is no difference in the $\mathrm{C}$ stock between naturally regenerated ( $844 \pm$ $58 \mathrm{Mg} \mathrm{C} \mathrm{ha}^{-1}$ ) and anthropogenic restored mangroves (889 $\pm 111 \mathrm{Mg} \mathrm{C} \mathrm{ha}^{-1}$ ) after 35 years (Nam et al. 2016).

The amounts of potential sequestration in Vietnam, and indeed, globally, could be significant. Using the sequestration rates estimated in Vietnam's INDC (Hieu et al. 2016), if the Vietnamese mangrove area was restored to the 1943 area of 408,500 ha, there could potentially be an annual rate of sequestration of $6 \mathrm{Mt} \mathrm{CO}_{2}$ e. Globally, if coastal wetlands were restored to the 1990 area, the annual carbon sequestration would increase to around $160 \mathrm{Mt} \mathrm{CO}_{2} \mathrm{e}$ (Herr and Landis 2016). These estimates, or course, need to be moderated by the hazards described earlier in the paper from future climate change.

\section{Conclusion}

Mangroves are important coastal ecosystems providing invaluable and irreplaceable services to wildlife and human life, and their conservation is critical. Given their capacity to sequester and store carbon, mangrove restoration is likely to feature in many countries' future climate mitigation strategies. In Vietnam, restoration is critical because more than half of the mangrove areas have been lost since the 1940s. Mangrove restoration started in Vietnam in 1978; however, it is clear from this paper that there is much uncertainty regarding the area covered by the restoration program and the area successfully restored. While other benefits from this restoration are also claimed, these are often not quantified. There is a clear 
lack of monitoring of project performance, and developing inventory approaches to verify performance is a priority. This will be particularly important as carbon financing develops, and there is a need to verify rates of carbon sequestration for buyers of carbon credits. As new environmental markets develop (e.g. for biodiversity, marine habitat, coastal protection), it will be crucial that these environmental services are also properly measured and reported. Improved monitoring is thus required to not only report the area of restoration, but also the quality of this restoration.

Although there are successful stories of mangrove restoration, many restoration projects have been unsuccessful with low long-term survival rates most likely due to lack of consideration of the soil and hydrologic conditions and stressors that caused the mangrove loss, inappropriate species selection and lack of incentives to engage local residents in the longterm management of restored areas. It is suggested that restoration efforts should follow a protocol, such as outlined by Bosire et al. (2008), that includes the diagnosis of the causes of the deterioration or deforestation of the mangroves, setting a baseline, the planning of restoration activities and long-term monitoring of the restoration project. Projects should also proceed with a co-management approach with strong community participation in all activities, including planning, implementation, management and monitoring.

Acknowledgements We thank Le Hong Viet (GIS expert) and Le Sy Hoa (GIS expert, Institute for Forest Ecology and Environment, Vietnam National University of Forestry) for drawing the maps; Pham Ngoc Thanh (GIS expert, Research Institute for Forest Ecology and Environment, Vietnamese Academy of Forest Sciences) for drawing maps and providing data on Vietnamese mangroves.

Contribution of the co-authors N.T. Hai collected data and wrote the manuscript. R.J. Harper and B. Dell contributed main ideas and detailed comments. V.T. Phuong contributed general comments and expert insights.

Funding information Project funding was received from the Asia-Pacific Network for Global Change Research, Project CRRP2018-05MY. Nguyen Thi Hai is funded by a Murdoch University International Postgraduate Scholarship (MIPS). The funders had no role in study design, data collection and analysis, preparation of the manuscript, or decision to publish.

Data availability The datasets generated during and/or analysed during the current study are available from the corresponding author on reasonable request.

Open Access This article is licensed under a Creative Commons Attribution 4.0 International License, which permits use, sharing, adaptation, distribution and reproduction in any medium or format, as long as you give appropriate credit to the original author(s) and the source, provide a link to the Creative Commons licence, and indicate if changes were made. The images or other third party material in this article are included in the article's Creative Commons licence, unless indicated otherwise in a credit line to the material. If material is not included in the article's Creative Commons licence and your intended use is not permitted by statutory regulation or exceeds the permitted use, you will need to obtain permission directly from the copyright holder. To view a copy of this licence, visit http://creativecommons.org/licenses/by/4.0/.

\section{References}

Adger WN, Kelly PM, Tri NH (1997) Valuing the products and services of mangrove restoration. Commonwealth Forest Rev 76:198-202

Alexander S, Nelson CR, Aronson J, Lamb D, Cliquet A, Erwin KL, Finlayson CM, De Groot RS, Harris JA, Higgs ES (2011) Opportunities and challenges for ecological restoration within REDD+. Restor Ecol 19:683-689

Alongi DM (2012) Carbon sequestration in mangrove forests. Carbon Mgnt 3:313-322

Alongi DM (2008) Mangrove forests: resilience, protection from tsunamis, and responses to global climate change. Estuar Coast Shelf Sci $76: 1-13$

Barbier EB, Hacker SD, Kennedy C, Koch EW, Stier AC, Silliman BR (2011) The value of estuarine and coastal ecosystem services. Ecol Monogr 81:169-193

AMDI (2015) Final evaluation of the mangrove plantation and disaster risk reduction in the period of 2011-2015. Asian Management and Development Institute, Hanoi www.rcrc-resilience-southeastasia. org/wp-content/uploads/2016/01/MP-DRR-finalreport-26Oct.pdf

Barnuevo A, Asaeda T, Sanjaya K, Kanesaka Y, Fortes M (2017) Drawbacks of mangrove rehabilitation schemes: lessons learned from the large-scale mangrove plantations. Estuar Coast Shelf Sci 198:432-437

Beland M, Goita K, Bonn F, Pham T (2006) Assessment of land-cover changes related to shrimp aquaculture using remote sensing data: a case study in the Giao Thuy District, Vietnam. Int J Remote Sens 27: $1491-1510$

Benthem W, Van Lavieren L, Verheugt W (1999) Mangrove rehabilitation in the coastal Mekong Delta, Vietnam. In: Streever W (ed) An International Perspective on Wetland Rehabilitation. Springer, Dordrecht, pp 29-36

Bolte P, Barnaby F, Rahmadana M, Cuc N (2011) Planting projection: evaluation of community-based mangrove reforestation and disaster preparedness programme, 2006-2010. Geneva, International Federation of Red Cross and Red Crescent Societies http://www. ifrc.org/docs/Appeals/annual11/MAAVN00111myr-PlantingProtection-April-2011-EN.pdf

Borrini-Feyerabend G, Dudley N, Jaeger T, Lassen B, Broome NP, Phillips A (2012) Governance of protected areas: from understanding to action. The World Conservation Union (IUCN), Gland, Swizerland

Bosire JO, Dahdouh-Guebas F, Walton M, Crona BI, Lewis R, Field C, Kairo JG, Koedam N (2008) Functionality of restored mangroves: a review. Aquat Bot 89:251-259

Broadhead J (2011) Reality check on the potential to generate income from mangroves through carbon credit sales and payments for environmental services. In: Regional Fisheries Livelihoods Programme for South and Southeast Asia (GCP/RAS/237/SPA) Field project document $37 \mathrm{pp}$

Buckingham K, Hanson C (2015) The restoration diagnostic. Case example: restoration of mangrove forests in Vietnam. World Resources Institute, Washington DC

Carew-Reid J (2008) Rapid assessment of the extent and impact of sea level rise in Viet Nam. International Centre for Environment Management (ICEM), Brisbane $82 \mathrm{pp}$

Cat NN, Tien PH, Sam D, Binh N (2006) Status of coastal erosion of Viet Nam and proposed measures for protection. Food and Agriculture Organization of the United Nations, Rome, http://www.fao.org/ forestry/11286-08d0cd86bc02ef85da8f5b6249401b52f.pdf 
Clough B, Tan DT, Buu DC (2000) Canopy leaf area index and litter fall in stands of the mangrove Rhizophora apiculata of different age in the Mekong Delta, Vietnam. Aquat Bot 66:311-320

Dale P, Knight J, Dwyer P (2014) Mangrove rehabilitation: a review focusing on ecological and institutional issues. Wetl Ecol Manag 22:587-604

De Graaf G, Xuan T (1998) Extensive shrimp farming, mangrove clearance and marine fisheries in the southern provinces of Vietnam. Mangrove Salt Marshes 2:159-166

De Jong W, Do D, Van Hung T (2006) Forest Rehabilitation in Vietnam: Histories, Realities, and Future: Histories, Realities, and Future. CIFOR, Jakarta https://www.cifor.org/publications/pdf_files/ Books/BDeJong0601.pdf

Dijksma R, Van Loon A, Van Mensvoort M, Van Huijgevoort M, Te Brake B (2010) An extended hydrological classification for mangrove rehabilitation projects: a case study in Vietnam. In: Hoanh CT, Szuster BW, Suan-Pheng K, Ismail AM (eds) Tropical Deltas and Coastal Zones: Food Production, Communities and Environment at the Land-Water Interface, vol 9. CABI International, Wallingford, pp 384-397

Donato D, Kauffman JB, Murdiyarso D, Kurnianto S, Stidham M, Kanninen M (2011) Mangroves among the most carbon-rich forests in the tropics. Nat Geosci 4:293-297

Duke NC, Meynecke J-O, Dittmann S, Ellison AM, Anger K, Berger U, Cannicci S, Diele K, Ewel KC, Field CD (2007) A world without mangroves? Science 317:41-42

EJF (2003) Risky Business: Vietnamese Shrimp Aquaculture - Impacts and Improvements. Environmental Justice Foundation, London http://animalscience2.ucdavis.edu/ans119/PDF files/DIS-03SHRIMP-AQUACULTENV-07.pdf

Ellison AM (2000) Mangrove restoration: do we know enough? Restor Ecol 8:219-229

FAO (2007) The World's mangroves 1908-2005. FAO forestry paper 153. Food and Agriculture Organization of the United Nations, Rome

FAO (2012) FRA 2015 Terms and Definitions. Forest Resources Assessment Working Paper 180. Food and Agriculture Organization of the United Nations, Rome

FAO (2018) National Aquaculture Sector Overview: VietNam. Food and Agriculture Organization of the United Nations, Rome http://www. fao.org/fishery/countrysector/naso_vietnam/en

Ferreira AC, Ganade G, de Attayde JL (2015) Restoration versus natural regeneration in a neotropical mangrove: effects on plant biomass and crab communities. Ocean Coast Manag 110:38-45

Field CD (1995) Impact of expected climate change on mangroves. Hydrobiologia 295:75-81

Field CD (1999) Mangrove rehabilitation: choice and necessity. Diversity Function Mangrove Ecosyst Hydrobiologia 413:47-52

Gilman E, Ellison J, Sauni I, Tuaumu S (2007) Trends in surface elevations of American Samoa mangroves. Wetl Ecol Manag 15:391-404

Giri C, Ochieng E, Tieszen LL, Zhu Z, Singh A, Loveland T, Masek J, Duke N (2011) Status and distribution of mangrove forests of the world using earth observation satellite data. Glob Ecol Biogeogr 20: 154-159

Gupta H, Kao SJ, Dai M (2012) The role of mega dams in reducing sediment fluxes: a case study of large Asian rivers. J Hydrol 464465:447-458

Hawkins S, Robertson S, Thu Thuy P, Xuan To P, McNally R, Van Cuong C, Dart P, Xuan Phuong P, Brown S, Vu N (2010) Roots in the water: legal frameworks for mangrove PES in Vietnam. Katoomba Group's Legal Initiative Country Study Series. Forest Trends, Washington, DC

Herr D, Landis E (2016) Coastal blue carbon ecosystems. Opportunities for nationally determined contributions. Policy Brief. IUCN, Gland Switzerland and The Nature Conservancy, Washington DC
Hieu N, Thuc T, Tan P, Huong H, Thang N, Trang D, Huong C (2016) Viet Nam's intended nationally determined contribution. Internationale Zusammenarbeit (GIZ) GmbH Vietnam, Hanoi

Hoi CN (2012) Investing in coastal ecosystems: a guiding document for journalists about the role and importance of coastal ecosystems. IUCN: gland, Switzerland, https://www.iucn.org/sites/dev/files/ content/documents.iucn_sach_dung_13_12_2012_en_final.Pdf: $27 \mathrm{pp}$

Hong PN (1996) Mangrove destruction for shrimp rearing in minh Hai, Viet Nam: its damage to natural resources and the environment. SEAFDEC Asian Aquacult 18:6-11

Hong PN (2001) Reforestation of mangroves after severe impacts of herbicides during the the Viet Nam war: the case of Can Gio. Unasylva 52(207):57-60

Hong PN (2008) Mangroves and coastal dwellers in Vietnam - a long and hard journey back to harmony. Commemorative Lecture, Kyoto University, Japan, http://www.ibrarian.net/navon/paper/2008 The International_Cosmos_PrizeCommemorative_pdf?paperid $=$ 14326266

Hong PN, San HT (1993) Mangroves of Vietnam. IUCN, Bangkok, $173 \mathrm{pp}$

Joffre O (2010) Mangrove dynamics in Soc Trang Province 1889-1965. Management of Natural Resources in the Coastal Zone of Soc Trang Province. Deutsche Gesellschaft fur Technische Zusammenarbeit (GTZ) GmbH, Bonn, Germany 60pp

Kauffman JB, Donato D (2012) Protocols for the measurement, monitoring and reporting of structure, biomass and carbon stocks in mangrove forests. Working Paper 86. Center for International Forestry Research (CIFOR), Bogor, Indonesia 40 pp

Kempinski J, Cuc N (2009) Review of CARE's community based mangrove reforestation and management project, Thanh Hoa Province, Viet Nam. Evaluation Report. The International Centre for Environmental Management (ICEM), Brisbane, Australia 30pp

Krauss KW, McKee KL, Lovelock CE, Cahoon DR, Saintilan N, Reef R, Chen L (2014) How mangrove forests adjust to rising sea level. New Phytol 202:19-34

Lai TP (2008) Fisheries co-management in Vietnam: Issues and approach. In: IIFET 2008, Proceedings of the Fourteenth Biennial Conference of the International Institute of Fisheries Economics \& Trade, July 22-25, 2008, Nha Trang, Vietnam: Achieving a Sustainable Future: Managing Aquaculture, Fishing. Trade and Development. Compiled by Ann L. Shriver. International Institute of Fisheries Economics \& Trade, Corvallis, Oregon, USA

Le HNN, Wolanski E, Tran TC, Haruyama S, Nguyen HN (2007) The combined impact on the flooding in Vietnam's Mekong River delta of local man-made structures, sea level rise, and dams upstream in the river catchment. Estuar Coast Shelf Sci 71:110-116

Le HD, Smith C, Herbohn J, Harrison S (2012) More than just trees: assessing reforestation success in tropical developing countries. $\mathrm{J}$ Rural Stud 28:5-19

Lebel L, Tri NH, Saengnoree A, Pasong S, Buatama U, Thoa LK (2002) Industrial transformation and shrimp aquaculture in Thailand and Vietnam: pathways to ecological, social, and economic sustainability? AMBIO: J Human Environ 31:311-323

Lewis RR (2005) Ecological engineering for successful management and restoration of mangrove forests. Ecol Eng 24:403-418

Lewis RR (1989) Wetlands restoration/creation/enhancement terminology: suggestions for standardization. In: Kusler JA, Kentula ME (eds) Wetland creation and restoration: the status of the science, 2nd edn. Island Press, Washington, DC, pp 417-419

Lewis R (2001) Mangrove restoration: costs and benefits of successful ecological restoration. Proceedings of the Mangrove Valuation Workshop, Universiti Sains Malaysia, Penang, 4-8 April, 2001. Beijer International Institute of Ecological Economics, Stockholm, pp 4-8 
Lovelock CE, Ellison J (2007) Vulnerability of mangroves and tidal wetlands of the Great Barrier Reef to climate change. Part II: species and species groups. In: Johnson JE, Marshall PA (eds) Climate change and the Great Barrier Reef: a vulnerability assessment. Great Barrier Reef Marine Park Authority, Townsville, pp 238-269

Macintosh D, Ashton E (2003) Draft code of conduct for the sustainable management of mangrove ecosystems. World Bank, Washington

Mackenzie JR, Duke NC, Wood AL (2016) The Shoreline Video Assessment Method (S-VAM): using dynamic hyperlapse image acquisition to evaluate shoreline mangrove forest structure, values, degradation and threats. Mar Pollut Bull 109:751-763

MARD (2014) Coastal forest protection and development plan to respond to climate change for the period 2015-2020 (approved at decision 120/QD-TTg dated 22rd January 2015 of Vietnamese Prime Minister). Ministry of Agriculture and Rural Development, Hanoi

MARD (2015) Synthesis report: master plan on shrimp cultivation in Mekong River Delta of Vietnam to 2020, vision to 2030. Ministry of Agriculture and Rural Development, Hanoi

McLeod E, Salm RV (2006) Managing mangroves for resilience to climate change. IUCN Resilience Science Group Working Paper Series No 2. IUCN, Gland 64pp

McNally R, McEwin A, Holland T (2011) The potential for mangrove carbon projects in Vietnam. Netherlands Development Organization (SNV). The Hague, Netherlands, http://www.bibalex.org/ search4dev/files/419125/442099.pdf

Millennium Ecosystem Assessment (2005) Ecosystems and Human Well-being: Synthesis. Island Press, Washington, DC 137pp

Nam VN, Sasmito SD, Murdiyarso D, Purbopuspito J, MacKenzie RA (2016) Carbon stocks in artificially and naturally regenerated mangrove ecosystems in the Mekong Delta. Wetl Ecol Manag 24:231244

Nghiem T, Tyler S (2017) Mangrove restoration in a degrated peri-urban site in central Vietnam: Variable success in different villages. ISETInternational, Hanoi, https://docs.wixstatic.com/ugd/558f8a c71ea0274268463088762692a165788f.pdf

Nguyen T, Van Tam N, Parnell KE (2016) Community perspectives on an internationally funded mangrove restoration project: Kien Giang province, Vietnam. Ocean Coast Manag 119:146-154

Osbeck M, Powell N, Hoang Tri N, Quynh Dao Q (2011) Reconciling the multiple dimensions of rural livelihoods in mangrove systems in the Red River Delta. In: Powell N, Swartling AG, Ha HM (eds) Stakeholder agency and rural development policy: articulating cogovernance in Vietnam. World Agroforestry Centre (ICRAF), Hanoi, pp 97-108

Pham T (2011) Mangroves of Soc Trang 1965-2007. Management of natural resources in the Coastal Zone of Soc Trang Province, Vietnam Deutsche Gesellschaft für Internationale Zusammenarbeit (GIZ) GmbH, Eschborn http://coastal-protectionmekongdelta.com/ download/library/126.STMangroves1965to2007.2011_EN.pdf

Powell N, Osbeck M, Tan SB, Toan VC (2011a) Mangrove restoration and rehabilitation for climate change adaptation in Vietnam. World Resources Report Case Study World Resources Report, Washington $\mathrm{DC}$

Powell N, Gerger Swartling Ä, Hoang MH (2011b) Stakeholder agency and rural development policy: articulating co-governance in Vietnam. ICRAF World Agroforestry Centre, Hanoi, $166 \mathrm{p}$

Primavera JH, Esteban JMA (2008) A review of mangrove rehabilitation in the Philippines: successes, failures and future prospects. Wetl Ecol Manag 16:345-358

Que N, P Thinh (2012) Restoration of coastal mangrove forest in Vietnam in Annex III - evaluation reports of the baseline projects to green climate fund funding proposal. http://www.adaptation-undp.org/ sites/default/files/resources/evalutation_report_of the baseline project.pdf

Reay SD, Norton DA (1999) Assessing the success of restoration plantings in a temperate New Zealand forest. Restor Ecol 7:298-308
Red Cross (2012) Mangrove plantation in Viet Nam: measuring impact and cost benefit. International Federation of Red Cross and Red Crescent Societies, Geneva, https://www.ifrc.org/Global/ Publications/disasters/reducing_risks/Case-study-Vietnam.pdf

Reed S, Nghi N, Minh N, Lien H, Hung T, Thien N, Anh N (2015) Building coastal resilience in Vietnam: An integrated, communitybased approach to mangrove management, disaster risk reduction, and climate change adaptation. CARE Australia, Canberra https:// www.careclimatechangeorg/wp-content/uploads/2016/02/BuildingCoastal-Resilience-in-Vietnampdf

Richards DR, Friess DA (2016) Rates and drivers of mangrove deforestation in Southeast Asia, 2000-2012. Proc Natl Acad Sci 113:344 349

Rivera-Monroy VH, Lee SY, Kristensen E, Twilley RR (2017) Mangrove ecosystems: a global biogeographic perspective: structure, function, and services. Springer Nature, Cham

Schmitt K (2012) Mangrove planting, community participation and integrated management in Soc Trang Province, Viet Nam. In: Macintosh DJ, Mahindapala R, Markopoulos M (eds) Sharing lessons on mangrove restoration, Bangkok, Thailand: mangroves for the future and gland. IUCN, Switzerland, pp 205-226

Schmitt K, Duke NC (2014) Mangrove management, assessment and monitoring. In: Kohl M, Pancel L (eds) Tropical forestry handbook. Springer, Berlin, pp 1-29

SNV (2016) MAM 1: Promoting Ecosystem-Based Adaptation through Reforestation and Sustainable Use of Mangroves. Netherlands Development Organization, The Hague http://www.snv.org/ project/mangroves-and-markets\#results

Spalding M (2010) World atlas of mangroves. Earthscan, New York

Streever B (1999) An international perspective on wetland rehabilitation. Kluwer Academic Publishers, Dordrecht

Stubbs BJ, Saenger P (2002) The application of forestry principles to the design, execution and evaluation of mangrove restoration projects. Bois et Forêts des Tropiques 56:5-21

Suda S (2013) Findings from our mangrove restoration activities over 30 years. Global Environmental Research, Miscellaneous Note 17/ 2013; pp. 189-197. http://www.airies.or.jp/attach.php/ 6a6f75726e616c5f31372d32656e67/save/0/0/17_2-7.pdf

Takagi H, Thao ND, Esteban M (2014) Tropical cyclones and storm surges in southern Vietnam. In: Thao ND, Takagi H, Esteban M (eds) Coastal disasters and climate change in Vietnam: engineering and planning perspectives. Elsevier, Berlin, pp 3-16

Thomas N, Lucas R, Bunting P, Hardy A, Rosenqvist A, Simard M (2017) Distribution and drivers of global mangrove forest change, 1996-2010. PLoS One 12:e0179302

Thu PM, Populus J (2007) Status and changes of mangrove forest in Mekong Delta: case study in Tra Vinh, Vietnam. Estuar Coast Shelf Sci 71:98-109

Thuc T, Thang N, Huong H, Kien M, Hien N, Phong D (2016) Climate change and sea level rise scenarios for Vietnam. Ministry of Natural Resources and Environment (MONRE), Hanoi https://www. researchgate.net/profile/Thuc_Tran/publication/318875854 Climate_Change and_Sea_Level_Rise_Scenarios for_Viet $\mathrm{Nam}$-__ Summary_for_Policymakers/1inks/ $5 \mathrm{a} 3 \mathrm{cadb} \overline{\mathrm{b}} \mathrm{a} 6 \mathrm{6fdcc} 21 \mathrm{~d} 878 \mathrm{~b} 1 \overline{6} 7 /$ Climate-Change-and-Sea-Level-RiseScenarios-for-Viet-Nam-Summary-for-Policymakers.pdf

Tien PH, Van Cu N (2005) Forecasting the erosion and sedimentation in the coastal and river mouth areas and preventive measures. State level research project, Hanoi 497pp

Tobey J, Clay J, Vergne P (1998) Maintaining in balance: the economic, environmental and social impacts of shrimp farming in Latin America. Coastal Management Report \#2202. University of Rhode Island, Coastal Resources Centre, Narragansett, Rhode Island USA, $62 \mathrm{pp}$ 
Tri NH, Adger W, Kelly P (1998) Natural resource management in mitigating climate impacts: the example of mangrove restoration in Vietnam. Glob Environ Chang 8:49-61

Tri NH, Hong P, Adger WN, Kelly PM (2001) Mangrove conservation and restoration for enhanced resilience. In: Adger WN, Kelly PM, Ninh NH (eds) . Routledge, London, pp 136-153

Tuan, Hong PN, Hoc TQ (2010) Problems of coastal environment and restoration in Vietnam. The Third International Workshop Yearbook of Vietnam, Hanoi 20pp

Tuan, Tinh BD (2013) Cost-benefit analysis of mangrove restoration in Thi Nai Lagoon, Quy Nhon City, Vietnam, Asian Cities Climate Resilience. Working Paper Series 4:2013. IIED, London 50 pp

UNDP (2015) Funding proposal: Improving the resilience of vulnerable coastal communities to climate change related impacts in Vietnam. United Nations Development Program Vietnam, Hanoi http://www. vn.undp.org/content/dam/vietnam/docs/Publications/FPUNDP281215-5708.pdf

Valiela I, Bowen JL, York JK (2001) Mangrove forests: one of the world's threatened major tropical environments. Bioscience 51:807-815

Van Loon AF, Te Brake B, Van Huijgevoort MH, Dijksma R (2016) Hydrological classification, a practical tool for mangrove restoration. PLoS One 11:e0150302

Ward RD, Friess DA, Day RH, MacKenzie RA (2016) Impacts of climate change on mangrove ecosystems: a region by region overview. Ecosyst Health Sustainabil 2(4):e01211. https://doi.org/10.1002/ ehs 2.1211
WB (2008) Vietnam - Coastal Wetlands Protection and Development Project (English). World Bank, Washington http://www. documentsworldbankorg/curated/en/731991468174545655/pdf/ ICR3750P0425680Box334107B01PUBLIC1pdf

WB (2017) Vietnam - Forest Sector Modernization and Coastal Resilience Enhancement Project. World Bank, Washington https:// www.gtaide/GTAI/Content/DE/Trade/Fachdaten/PRO/2017/06/ Anlagen/PRO201706305005pdf?v=1

Westing AH (1983) The environmental aftermath of warfare in Viet Nam. Nat Resour J 23:365-390

Witter S (1994) Mangrove planting in Vietnam. Development in Practice 4:130-132

Wolanski E, Elliott M (2015) Estuarine ecohydrology: an introduction. Elsevier, Amsterdam

Wösten J, De Willigen P, Tri N, Lien T, Smith S (2003) Nutrient dynamics in mangrove areas of the Red River Estuary in Vietnam. Estuar Coast Shelf Sci 57:65-72

Wylie L, Sutton-Grier AE, Moore A (2016) Keys to successful blue carbon projects: lessons learned from global case studies. Mar Policy 65:76-84

Publisher's note Springer Nature remains neutral with regard to jurisdictional claims in published maps and institutional affiliations. 